\title{
太陽熱発電システムにおける集熱温度の 最適設定に関する考察
}

\author{
正 員 藤 原 正 純 (電総研) \\ 正員谷 夫 (電総研)
}

\section{1.はじめに}

太陽エネルギーの一つの特徵として, 日射の非定常 性がある。日射入力は太陽の日周運動や雲の影響によ り時間的に変動するエネルギー源である。太陽熱発電 システムは，乙のような変動する入力を熱エネルギー として収集し，熱機関を用いて発電するシステムであ る。熱機関への入力温度を一定とするために，集熱温 度は通常, 一定值に設定される。従って, 集熱フィ一 ルドでは, 変動する日射入力を一定温度の熱出力に変 換して集熱する必要がある。しかしながら，熱機関へ の入力温度に融通性がある場合には，日射入力に応じ て集熱温度を調節し，その温度で熱機関を駆動し発電 を行ったほうが, 一定温度で集熱・発電した場合より あ電気出力が増大するととが期待される。例えば，熱 機関を二段にカスケーディングした複合発電システム を採用した場合には，日射強度に応じて集熱温度が二 段階に選択できるととになる。また，日射入力に応じ て常に最適な集熱温度で集熱し, 補助熱源による追加 熱で熱機関へ一定温度の熱を供給するシステムむ考え られる。

本論文は，てのように集熱温度の選択可能なシステ 厶を構成した場合の有効性を定量的に評価することを 目的としている。複合発電を導入したンーラーシステ ムの実験設備に関する設諎と運転特性に関する報告 は既に行われているが(1) (3)，乙れらの報告は気象条 件, 集熱器特性, 集熱温度, 発電容量などのパラメー タを限定したうえでの考察である。本論文では，集熱 系のエクセルギー出力により評価を行っているため,

Optimum Plan for Setting the Heat Collection Temperature in Solar Thermal Power Plants. By Masanori Fujiwara, Member \& Tatsuo Tani, Member (Energy Division, Electrotechnical Laboratory).

藤原正純 : 正員, 電子技術総合研究所エネルギー部

谷 辰夫: 正員, 電子技術総合研究所エネルギー部
集熱温度の設定方法に関してより広範なパラメータサ ーベイが可能である。

エクセルギーとは, 系と外界との状態差を利用して 取出し得る最大の力学的エネルギーと定義される(4)。 太陽熱集熱器では，日射入力と外気温を与えた場合に， エクセルギー出力を最大にする集熱温度は, 一意的に 定まるととが示されている(5)-(7)。従って, 環境条件 に応じて集熱温度を選択した場合の有効性は，集熱系 のエクセルギー出力を比較するととにより, 定量的に 評価できることになる。集熱系の出力をエクセルギー を用いて評価することは, 蓄熱系や発電系などの集熱 系以外のサブシステムを非可逆性のない理想的なシス テムと仮定するととに相当する。

このようにエクセルギーを用いるととにより，集熱 系と他のサブシステムとを分離して評価し得ることに なり, 評価手順が大幅に簡略化される。このため, 複 数の集熱温度設定値を持つような複雑なシステムの評 価む可能となる。当然, 全体のシステムをモデル化し シミュレーションを行うことにより, より厳密な詿洒 は可能であるが，そのようなシステムの最適化を図り 相互に比較するととは容易ではない。日射条件と集熱 系は, システム全体にとり最む重要な要素であり, 本 論文では, とれら二つの要素の組合せについて評価を 行っており，太陽熱発電システムの設計にあたって有 意義な指針を与え得ると考えられる。

\section{2. システム構成と計算手順}

〈2・1〉 システムモデル 本論文では，集熱シス テムとして東西一軸追尾の桶型放物面集光集熱器 ${ }^{(2)(9)}$ を集熱フィールドに配列したものを考える。具体的に は幅 $2.49 \mathrm{~m}$, 長さ $6.4 \mathrm{~m}$ の樋型放物面鏡によるシステ ム ${ }^{(9)}$ を想定している。東西一軸追尾とは, 追尾の回転 軸が東西方向に平行で, その軸と開口面法線と太陽之 が同一平面上にあるように追尾する方式である。シス 
テムモデルとしては次のような Hottel-Whillier-Bliss モデル(8)を採用した。

$$
\begin{aligned}
T_{c}= & T_{i}+\tau \alpha H_{T} A_{a} / U_{L} A_{r} \\
& +\left(T_{i}-T_{a}-\tau \alpha H_{T} A_{a} / U_{L} A_{r}\right) \\
& \times \exp \left(-F^{\prime} U_{L} A_{r} / \dot{m} C_{p}\right) \quad \ldots \ldots .
\end{aligned}
$$

ここで，T。:集熱温度 (集熱系出口温度),

$T_{i}$ : 集熱系入口温度, $T_{a}$ : 外気温, $\dot{m}$ : 翼量

流量, $H_{T}$ : 日射入力, $A_{a}$ : 集熱器開口面積,

$A_{r}$ : 集熱部表面積, $C_{p}$ : 熱媒体比熱, $F^{\prime}:$ 集

熱器効率係数, $U_{L}$ : 熟損失係数, $\tau \alpha$ : 透過

率一吸収率積

このモデルでは，通常，熱損失保数 $U_{L}$ 洁一定值と して扱われる。しかしながら，放射提失が顕著な集熱 器では, 熱損失の温度依存性が強い。そこで, $U_{L}$ の 温度依存性を考慮したモデルについてあ检討を行うこ ととし，UL について次のような二とおりのモデルを 設定した。

$$
\begin{aligned}
& \text { モデル I : } U_{L}=\text { const } \\
& \text { モデルII : } U_{L}=\sigma \varepsilon\left(T_{m}{ }^{4}-T_{i}{ }^{4}\right) /\left(T_{m}-T_{i}\right)
\end{aligned}
$$

$$
\begin{aligned}
& T_{m}=\left(T_{c}+T_{i}\right) / 2 \ldots \ldots \ldots \ldots \ldots \ldots \ldots(4) \\
& \text { ここで, } \sigma: \text { ステファン・ボルッマン定数 } \\
& \left(5.67 \times 10^{-8} \mathrm{Wm}^{-2} \mathrm{~K}^{-4}\right), \varepsilon: \text { 実效放射率 }
\end{aligned}
$$

モデルIは熱損失として伝導損失が顕著な場合をも デル化しており，モデルIは放射損失が顕著な場合を モデル化している。通常の集熱器では, 放射・対流・ 伝導の 3 種の熱損失が混在しており。 $U_{L}$ の温度俵存 性はモデル I とIIの中閻的な振舞をすると考えられ る。

また，集熱器效率系数 F'については一定値として いるが，Fは衤部の形状と熱損失係数 $U_{L}$ および 集熱管と熱媒体の熱伝達率により定まる性能パラメー タであり，熱伝遵率は熱媒体の物性值と流速に传存す る。従って，啟密には $F^{\prime}$ を温度・流量の関数として 与えるべきであるが，集熱系全体の質量流量より個々 の集熱器の流速を与えるには，集熱管の管径および集 愁器の直並列阅する焛列方法を与える必要があり， 個々のケースに応じて詳細なモデル化が必要となる。 また， $F^{\prime} の U_{L}$ に対する依存性を考慮に入れるため には，集熱部の具体的形状を与える必要がある。本諭 文では，このような問题の詳細に立入るのを避けるた め，F'は一定值として計算を行った。

集熱系加らの瞬時熱出力 $\varepsilon$ は，次式で与光られる。

$$
\varepsilon_{t}=\dot{m} C_{p}\left(T_{c}-T_{i}\right)
$$

(5)式では, 比熱 $C_{p}$ の温度依存性は無視してい
る。その場合、集熱系の瞬時エクセルギー出力 $\varepsilon_{\ell}$ は 次式となる(5)。

$$
\varepsilon_{e}=\dot{m} C_{p}\left\{T_{c}-T_{i}-T_{a} \log _{e}\left(T_{c} / T_{i}\right)\right\}
$$

ただし（6)式では温度単位として絶刘温度を用い る必要がある。また，エクセルギー効率 ク。は次式で 定義した。

$$
\eta_{e}=\varepsilon_{e} / H_{T} A_{a}
$$

(1)〜 (7) 式に括いて, $\dot{m}$ と $C_{p}$ は常に熱流量 $\dot{m} C_{\text {p }}$ の形で表れており， $\dot{m} C_{p}$ を一括して一つの変数とし て扱うことが可能である。これらの式の導出において

$$
\int_{T_{i}}^{T_{c}} C_{p} d T=C_{p}\left(T_{c}-T_{i}\right) .
$$

と仮定しているが, 右辺の $C_{p}$ は $T_{i}<T<T_{0}$ の温度 領域に扝ける比熱の実効值を与えるものとすれば，相 比熱江温度依存性がある場合にも適用し得る。その場 合， $C_{p}$ は平均温度の関数上なるが，計算上は $\dot{m} C_{p}$ を一つの変数として取报うため，その関数形を与えな くても計算は可能である。結局，(1)〜（7)式におけ る变数は， $T_{c}, T_{i}, \dot{m} C_{p}$ の 3 個であり, 環境条件であ る日射入力 $H_{T}$ と外気温 $T_{a}$ とが与えられた場合， 3 個の変数のうち 2 個を定めれば(5)，(6)式の出力は 定まるととになる。以下，本論文では集熱系入口温度 $T_{i}$ が外気温 $T_{a}$ と等しい場合を取扱うこととし， $T_{\sigma}$ の目標値を満足するように, 日射入力に応じて熱流量 $\dot{m} C_{p}$ が制御されるシステムについて考察を行うこと よする。 $T_{i}$ を $T_{a}$ より毛高温化設定するシステムや， $T_{i}$ が萎熱量仙応じて変動するシステム白当然考えら れるが，本論文では $T i$ 亿ついては最す簡単なケース として $T_{i}=T_{a}$ の場合を取扱うとととした。

集熱系の性能パラメータは，次のように設定した。

$$
\begin{aligned}
& F^{\prime}=0.95, \tau \alpha=0.7, A_{a} / A_{r}=20 \text { (笨光比), } \\
& U_{L}=10 \mathrm{~W} / \mathrm{m}^{2} \mathrm{~K} \text { (モデル I), } \varepsilon=0.7 \text { (モデ } \\
& ル I I)
\end{aligned}
$$

ここで，開口面積 $A_{a}$ ，集熱部表面積 $A r$ の具体的 数值については，日射入力およびェクセルギー出力を 単位開口面皘あたりの值で与えるため必要がない。 $C_{p}$ の值も $\dot{m} C_{P}$ を変数として取扱うため，同様である。 これらの性能パラメータは, Hexcel 社の樋型放物面集 光集熱器と同程度の性能となるように設定した (9)。た だし，報告されている実験結果は $T_{c} \leqq 550 \mathrm{~K}$ の領域 に限られているため，それ以上の温度領域においては モデルＩとIにとでは集熱性能にかなりの差がある。图 $1(\mathrm{a}),(\mathrm{b}) K$ ，それぞれのモデルについてのエク七 ルギー効率曲線を示した。同図では， $T_{a}=T_{i}=300 \mathrm{~K}$ 




(a)

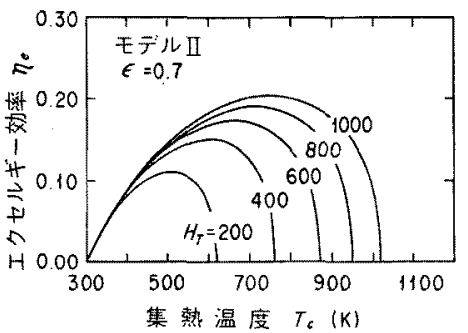

(b)

図 1 エクセルギー効率曲線

Fig. 1. Exergy efficiency curve.

とした。同図より，日射入力の増大に伴い，エクセル ギー效率香增大するが，一定の日射入力の下では，工 クセルギー効率を最大にする菒熱温度は一意的に定ま ることがわかる。モデルIでは，UL $U_{L}$ が一定であるた め高温部での効率の低下が緩やかになっている。

次に，一定温度で集熱した場合上日射入力に応じて 篹熱温度を調節した場合の比較を図 2 (a)，(b) に示 す。同図には，一定温度 $\left(T_{c}=670,600 \mathrm{~K}\right)$ で集熱し た場合のエクセルギ一効率 $\eta_{\mathrm{e}}\left(T_{t}=\mathrm{const}\right)$ と, 一定 日射入力下に拈けるエクセルギー効率の最大值 $n^{\text {opt }}$ 乩よびその上きの集熱温度 $T_{6}{ }^{\text {opt }}$ を示した。図 2 にお ける一定集熱温度は，後の計算結果加らわかるよう

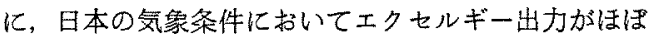
最大となる值を選定した。同図上り，列 ${ }^{\text {opt }}$ と $\eta_{e}\left(T_{c}=\right.$ const) の差は $H_{T} \leqq 200$ の低日射時と $H_{T} \geqq 800$ の高

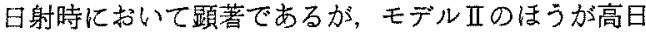
射封に㧍りる效率差は小さいことかわかる。これはも デルIでは温度上昇に伴い熱損失係数加急激に增大す るととに起因している。以上より，日射入力に応じて 策熱温度を調整し，常にエクセルギー効率が最大上な るように集熱すれば，エクセルギ一出力の積算侸は增 大し，この傾向はモデルIのほうが影著であることが わかる。

〈2-2〉気象データ 気象データとしては, HASP 栖準気象データ(10)の札幌，新舄，(新)東京, 高松, 高 知のデータを用いた。この気象データは1時間閪隔の

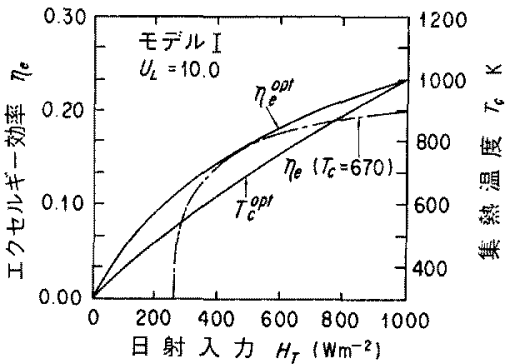

(a)

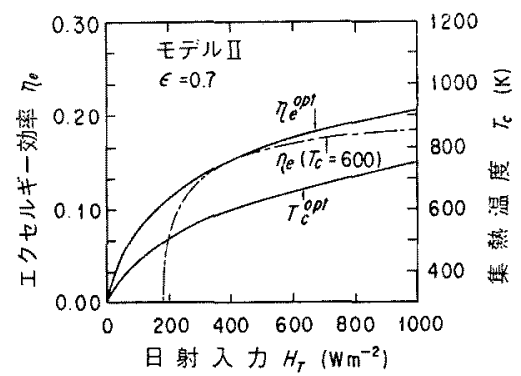

(b)

図 2 エクセルギ一効率と集熱湿度の最適徝

Fig. 2. Optimum value of exergy efficiency and heat collection temperature.

データであるため，日射入力の算出の際必要之なる太 陽位置は，気象データの中心時刻での位置在用いた。 太陽位策の匴には Walraven 氏(11)(12)のサブルーチ ンを用いた。集熱器への日射入力 $H_{T}$ は，法線面直達 日射量 $I_{B N}$ と水平面敬乱日射量 $I_{D N}$ を用いて, 次式 により算出した ${ }^{(8)}$ 。

$$
H_{T}=I_{B N} \sqrt{1-\sin ^{2} H \cos ^{2} \delta}+I_{D H} A_{r} / A_{a}
$$

ここで, $I_{B N}$ : 法線面直達日射量, $I_{D H}$ : 水平

面全天日射嶨， $\delta:$ 太陽赤緯， $H$ : 太陽時角

日射入力 $H_{T}$ の頻度分有之年間罳積日射入力の強 度別分布とを图3(a)，(b)に示す。図3（a）におい て, $100 \mathrm{~W} / \mathrm{m}^{2}$ 以下の日射時間が棈端に多いのは, (9)式第 2 項の散乱光の影響である。この項のエネル ギー入力全体に占める割合は，功り小さいしとが図 3(b)よりわ加る。た，图2に执いて效率差の著し い $200 \mathrm{~W} / \mathrm{m}^{2}$ 以下の低日射入力は，生起確率は高いが 入力エネルギー量としては小さいととがわかる。

〈2.3〉集熱モード以上のシステムモデルと気 象条件を用いて，I時間ごとの出力を算出するわけで おるが，そのためには集熱温度 $T_{。}$ の目標值を設定す る必要がある。本諭文では，集熱温度の設定方法とし て，次の三と扣りのモードを考えた。 


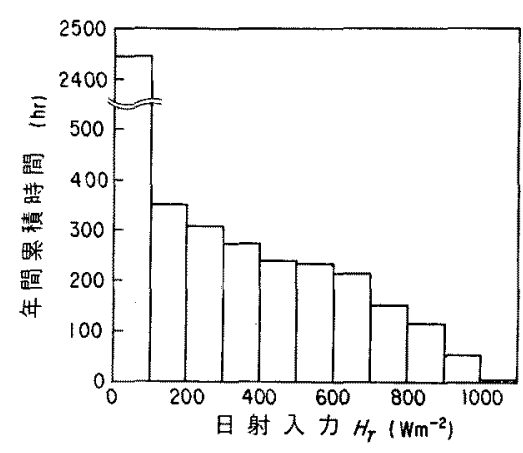

(a) 日射入力の頻度分布

(a) Frequency distribution of input solar radiation.

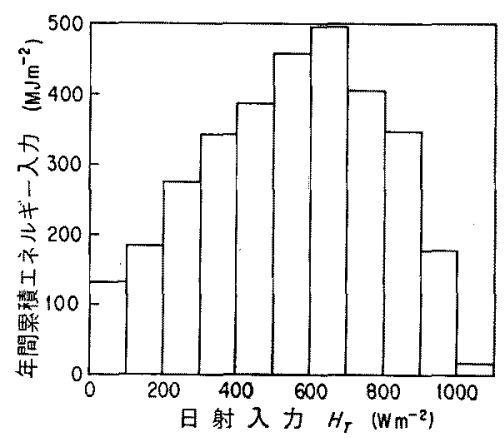

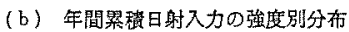

(b) Intensity distribution of yearly cumulative input solar radiation.

图 3

Fig. 3.

(i) SINGLE モード（S モード） 一段階の集熱 温度を設定し，日射条件により設定温度が満足で きない場合には，出力を０こする。

(ii) DOUBLE モード (Dモード) 二段階の集 熱温度を設定し，日射条件によりエクセルギ一出 力の高いほうの設定温度で集熱を行う。

(iii) FREE モード ( $F$ モード) 常にエクセルギ 一出力を最大とする集熱温度で集熱を行う。

$\langle 2 \cdot 4\rangle \quad シ ス テ ム$ 構成

以上のように集熱温度の設定方法が異ねると, 集熱 系以外のサブシステムの構成も罢なったすのとなる。 各集熱モードに対灾するシステム棈成国の例を図 4 (a) （d)に示す。(a)罒は $S$ モードに対忘するシ ステム構成図であり，一定温度で集熱・蓄熱を行い， 熱機関へ一定温度の一定熱流最を供給するシステムで ある。（b)図は $D$ モードに対応するシステム棈成図 であり，熱機関を2段にカスケーディングした複合発 電システムを導入した㘯合である。日射入力に忘じて 2 段階に集熱温度を選定し，集熱・蓄熱・発電を行う システムである。(c)図は $F$ モードに対忍するシス

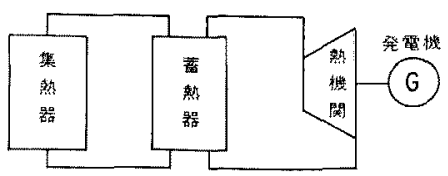

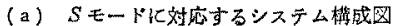

(a) System composition corresponding to $S$ mode.

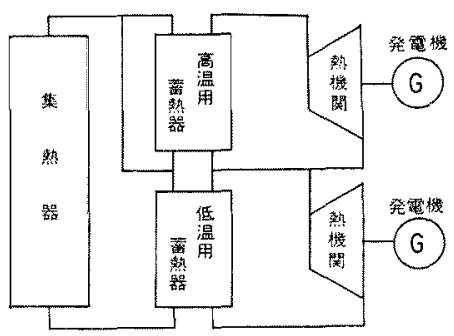

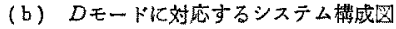

(b) System composition corresponding to $D$ mode.

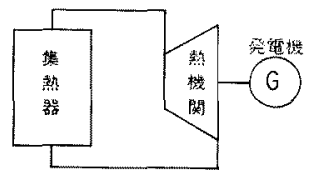

(c) Fモードに対応するシステム檽成图(1)

(c) System composition corresponding to $F$ mode (case I),

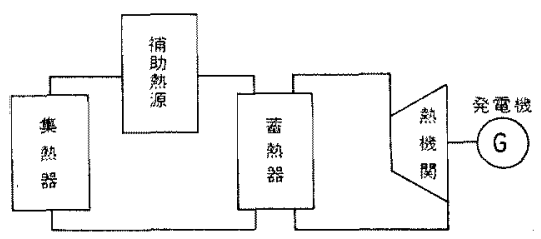

(d) Fモードに対応するシステム满成四（II）

(d) System composition corresponding to $F$ mode (case II)

园 4

Fig. 4.

テム構成図であり，エクセルギー出力を最大にする温 度で集熱した熱を直接熱機関へ供給するシステムであ る。乙の場合には，熱機関への入熱温度・入熱流量は 日射入力に仙じて変動する。とのシステムでは集熱温 度の変動する熱を混合せずに蓄熱するととは因難であ るため，蓄熱器は備えていない。(d)図も $F$ モード に対応するシステム棈成図であり，エクセルギー出力 を最大にする集熱温度で集熱を行った㣪, 補助熱源で 追加熱を行い一定温度の熱として蓄熱し発電するシス テムである。

このように集熱モードの違いに応じてシステム全体 の構成も異ったものよなるが，本諭文では集熱系以外 のサブシステムには非可逆性のない理想的なあのを想 定しており，それらのモデル化は全く行っていない。 蓄熱器・熱機関なよ゙の特性を考慮に入れる場合には， 
それらの容量を集熱面積に応じて最適な值に設定した うえで，各システムの出力を比較する必要があり，膨 大な作業量を要することになる。本論文のように集熱 系の特性のみを用いて各システムの優少をある程度の 精度で評洒することは，システムの構成法を検討する うえで有意義な指針を与え得る。以下，図4の各シス テムの出力を比較するうえでの問題点について簡単に 考察する。

集熱系以外での非可逆性については，図4の各シス テムが同程度の非可逆性を有すれば，出力の相対比較 を行なううえでは特に問題とはならない。集熱系以外 での非可逆性は ( c ) 図のシステムが熱機関への入力が 不安定であるため，最む大きいと考えられる。(b)図 のシステムも(a)図，(d)図のシステムと同一の規模 を考えれば，蓄熱器・熱機関が二段に分割されるた め，相対的保熱損失が大きくなり非可逆性む大きくな ると考元られる。図 4(a)，(b)のシステムの非可逆 性は同程度と考えられる。

また，本論文では(1)式のように定常状態の式を用 いて計算を行っており，システムの熱容量に起因する 非定常性については無視している。熱容量が大きい場 合には, システム全体が所定の温度に到達するまでに 余分の熱量が必要となり出力の低下をもたらす。との 点に関しても, 図 4 の各システムが同程度の熱容量を 有する場合には，出力の相対比較のうえで, 特に問题 とはならない。図4(c)のシステムでは蓄熱器を備え ていないため熱容量は小さくなるが，他のシステムに おいても熱機関への入熱流量が変動することを許せ ば，蓄熱器を除外することが可能である。また，図 4 (d)のシステムは補助熱源を借えているため, 出力が 安定化し非定常性に起团する損失が隇少するが，他の システムにおいても補助熱源を導入すれば，同様の効 果が期待し得る。従って，熱容量に関しては各モード における出力の相対比較を行なううえでは無視しても 差しつかえないと考光られる。

なお本諭文では, 熱機関の排熱温度は外気温と等し く, 排熱の有効利用上いう観点からの複合発電の長所 については考察していない。そのような観点から複合 発電を導入方ることは，図4（b)以外の各システムに おいてあ可能であり, 熱機関単独の問題として扱い得 る。

$\langle 2 \cdot 5\rangle$ 計算手順 気象データが 1 時間間隔で与 えられているため, 計算の時間間隔む1時間とした。 従って,システムの状態は，環境条件に忍じて 1 時間ご とにステップ状に変化することになる。これはシステ ムの熱容量がささく，その熱応答時間が 1 時間に比し
十分に短いと仮定することに相当する。各モードにお ける年間エクセルギー出力 $E_{\mathrm{a}}$ は， 1 時間ごとのエク セルギー出力を積算するととにより得られる。なお， 日射入力として $1 \mathrm{~m}^{2}$ あたりの值を与えるため，E。 $1 \mathrm{~m}^{2}$ の開口面皘劣たりの值を算出することになる。

\section{3. 計算結果と考察}

まず，Sモードの年間エクセルギー出力 $E$ 。在求め た。この值は当然, 集熱温度 $T$ 。の設定値により買な る。図 5 に東京におりる年間エクセルギー出力 $E$ ，の 集熱温度 $T_{f}$ 江対する依存性を示した。同図より，モ デル I では $T_{t}=650 \mathrm{~K}$ において, モデルIIでは $T_{t}=$

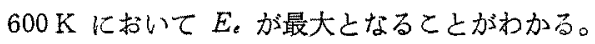

次に，東京に怙ける $D$ モードの年間エクセルギー 出力 $E_{e}$ の計算結果を図 $6(\mathrm{a}),(\mathrm{b})$ 飞示す。同図で は, 横軸に低温集熱温度 $T$ 。', 縦朝飞高温集熱温度

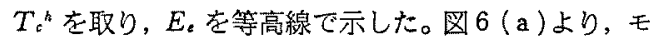
デルIでは $T_{c}{ }^{h}=765 \mathrm{~K}, T_{c}{ }^{l}=490 \mathrm{~K}$ 亿おいて, 図 6 (b)よりモデル II では $T_{\mathrm{c}}{ }^{h}=655 \mathrm{~K}, T_{c}{ }^{b}=490 \mathrm{KK}$ おいて E。は最大となるととがわかる。図5およで図 6(a)，(b)におけるピークの形状はかなり緩やかで あるため，気象条件の年々の変動炕よ， $S, D$ モー ドにおりる集熱温度設定值が，最道值よりずれるとと による影響は小さいと考えられる。

各モード，各地域における年間エクセルギー出力 $E$ 、の計算結果をま之めると表 1 のようになる。同表

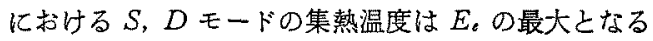
值を選択した。すすなわ各地域におりる因 5，図6 の最大値を抽出して比較を行った。集熱温度は $S$ モ ードではモデルIで 640〜700 K, モデルIIで 590〜 $620 \mathrm{~K}$ であった。同表より，Dモードを採用すること により，Sモードに対しモデルIで 7 10\%，モデル IIで 5〜7\% の出力の増大が見込まれ，Fニードで は，モデルIで 19２7\%，モデルIで 13〜20\% の増

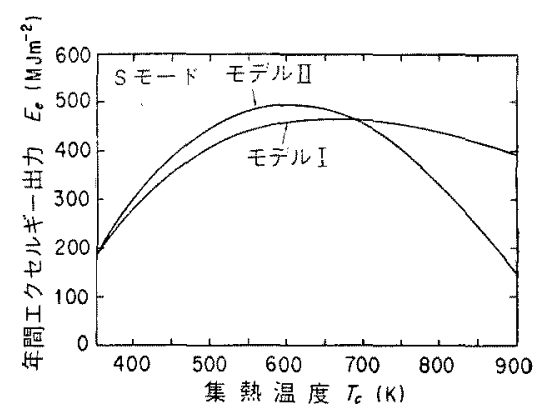

四 $5 S$ モードにおける年間エクセルギー出力

Fig. 5. Yearly exergy output of $S$ mode. 


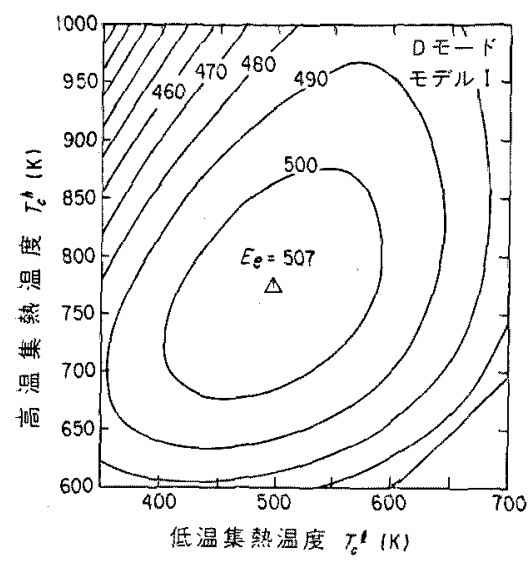

(a)

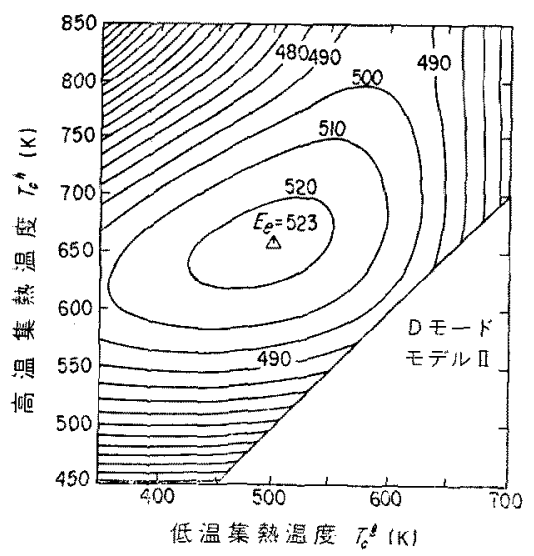

(b)

图 6 Dモードにおける年間エクセルギー出力

Fig. 6. Yearly exergy output of $D$ mode.

大が見込まれるととがわかる。モデルIIのはがが出力 の增大する割合が小さいのは，図2に括ける高日射時 の效率差がモデルIに比して相対的に小さくなってい ることに起因している。すなわち，モデルIIでは勧熱 温度の增大に伴い急激に熱損失係数 $U_{L}$ 妿增大する
ため，因1に示すように高温部での効率の低下がモデ ルIに比べ著しいこ之に起因している。通常の集熱器 のU゙ はモデルさとIIの中間的な温度依存性をすつと 考えられるので, $D, F$ モードの有效性毛両者の中間 の值婂なると考えられる。

との上う亿熱提失保数 $U_{L}$ の温度偖存性が $D, F モ$ 一ドの有効性にかなり影響を及济すととが判明したの て, 次に集熱器の断熱性能が向上し熱損失係数が低减 した場合について計算を行った。その結果を表 2 亿示 す。表 2 は $U_{L}=5 \mathrm{~W} / \mathrm{m}^{2} \mathrm{~K}$ (モデルI)， $\varepsilon=0.4$ (そデ ルII) の場合の計算結果である。熱損失係数が低減し たことにより，Sモードにおける集熱温度はモデルI で 860〜1,000K，モデルIIで 670 710 K と表 1 に 比して高くなる。また， $D, F$ モードでの $E_{e}$ の增大 する割合は，表 2 の心うが表 1 より全体的化小さく なって招り，熱損失保数の減少に伴い $D, F$ モードの 有効性は低下する傾向のあるととがわかる。

以上より，日本の標準的気象条件の下での $D$ モ一 ドの有效性は 4 10\% 程度，Fモードの有効性は 9 27\% 程度已見皘られる。乙れらの值仿気解条件お よび集熱器性能代より買なるが，その傾向として熱挰 失係数の小さいはど，あるいは放射挰失が相対的に顕 著なほど有効性が低下することが判明した。このよう に集熱温度を調節するととの効果は，さはど顕著では ない。因2亿示すようにその効果は低日射時之高日射 時に顕著であるが，図 $3(b)$ 亿示すようにその上うな 日射入力の積算值は比較的小さく，出力全体に対する 寄与が小さいことが，その主な理由である。図3(a) 代示すよう低日射状態の生起確率注高いので，䈎熱 温蛋を調節するシステムでは集熱可能な時間は長くな るか，出力の積算值にはあまり奇与しないととがかか る。

次に，以上の結果と図40各システムとの対态につ いて考察する。图 4(b)のシステムは $D$ モードに対 応し, 複合発電システムを導入しているが，ての場

表 1 年間エクセルギー出力の比較 $U_{L}=10$ (モデルI)， $\varepsilon=0.7$ (モデルII)

Table 1. Comparison of yearly exergy output $U_{L}=10$ (model I), $\varepsilon=0.7$ (model II).

\begin{tabular}{|c|c|c|c|c|c|c|}
\hline & & & \multirow{2}{*}{$\begin{array}{c}\text { 年闑日射入力 } \\
\left(\mathrm{MJ} / \mathrm{m}^{2}\right)\end{array}$} & \multicolumn{3}{|c|}{ 年間エクセルギー出力 $\left(\mathrm{MJ} / \mathrm{m}^{2}\right)$} \\
\hline & & & & $S モ-F$ & $D E-F($ 䄪 $S \in-F$ 比 $)$ & 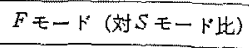 \\
\hline 札 & 䤐 & $\begin{array}{l}\text { モデルI } \quad\left(U_{L}=10\right) \\
\text { モデルI }(\varepsilon=0.7)\end{array}$ & 4,017 & $\begin{array}{l}553 \\
611\end{array}$ & $611(1.10)$ & $\begin{array}{l}666(1.20) \\
688(1.13)\end{array}$ \\
\hline 新 & 湡 & 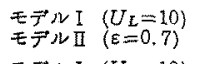 & 2,984 & $\begin{array}{l}413 \\
446\end{array}$ & $\begin{array}{l}451(1.09) \\
473(1.06)\end{array}$ & $\begin{array}{l}526(1.27) \\
533(1.20)\end{array}$ \\
\hline 東 & 京 & $\begin{array}{ll}モ テ ゙ ル I ~ & \left(U_{L}=10\right) \\
モ テ ゙ ル I I ~ & (\varepsilon=0,7)\end{array}$ & 3,210 & $\begin{array}{l}466 \\
494\end{array}$ & $\begin{array}{l}507(1.09) \\
523(1.06)\end{array}$ & $\begin{array}{l}588(1.26) \\
585(1.18)\end{array}$ \\
\hline 高 & 松 & $\begin{array}{ll}モ テ \breve{J ~ I ~} & \left(U_{L}=10\right) \\
モ テ ゙ ル I I I & (\varepsilon=0.7)\end{array}$ & 4,082 & $\begin{array}{l}614 \\
642\end{array}$ & $\begin{array}{l}664(1.08) \\
678(1.06)\end{array}$ & $\begin{array}{l}730(1.19) \\
727(1.13)\end{array}$ \\
\hline 高 & 知 & $\begin{array}{ll}モ テ ゙ ル I ~ & \left(U_{L}=10\right) \\
\text { モデルII } & (\varepsilon=0.7)\end{array}$ & 4,384 & $\begin{array}{l}695 \\
714\end{array}$ & $\begin{array}{l}746(1.07) \\
750(1.05)\end{array}$ & $\begin{array}{l}833(1.20) \\
812(1.14)\end{array}$ \\
\hline
\end{tabular}


表 2 年間エクセルギー出力の比較 $U_{L}=5$ (モデルI)， $\varepsilon=0.4$ (モデル II)

Table 2. Comparison of yearly exergy output $U_{L}=5$ (model I), $\varepsilon=0.4$ (model II).

\begin{tabular}{|c|c|c|c|c|c|c|}
\hline & & & \multirow{2}{*}{$\begin{array}{c}\text { 年間日射入力 } \\
\left(\mathrm{MJ} / \mathrm{m}^{2}\right)\end{array}$} & \multicolumn{3}{|c|}{ 年間エクセルギー出力 $\left(\mathrm{MJ} / \mathrm{m}^{2}\right)$} \\
\hline & & & & $s \neq-r$ & 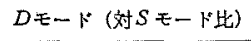 & $F モ ー ト$ (対 $S$ モード比) \\
\hline 机 & 野 & 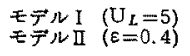 & 4,017 & $\begin{array}{l}800 \\
738\end{array}$ & $\begin{array}{l}869(1.09) \\
781(1.06)\end{array}$ & $\begin{array}{l}922(1.15) \\
814(1.10)\end{array}$ \\
\hline 新 & 潟 &  & 2,984 & $\begin{array}{l}597 \\
539\end{array}$ & $\begin{array}{l}642(1.08) \\
568(1.05)\end{array}$ & $\begin{array}{l}723(1.21) \\
605(1.12)\end{array}$ \\
\hline 東 & 京 & 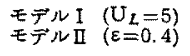 & 3,210 & $\begin{array}{l}667 \\
595\end{array}$ & $\begin{array}{l}714(1.07) \\
625(1.05)\end{array}$ & $\begin{array}{l}803(1.20) \\
668(1.12)\end{array}$ \\
\hline 高 & 森 & $\begin{array}{l}\text { モ゙ルI }\left(\mathrm{U}_{L}=5\right) \\
\text { モデルII } \\
(\varepsilon=0.4)\end{array}$ & 4,082 & $\begin{array}{l}872 \\
772\end{array}$ & $\begin{array}{l}933(1.07) \\
809(1.05)\end{array}$ & $\begin{array}{r}1,002(1.15) \\
844(1.09)\end{array}$ \\
\hline 高 & 狗 & $\begin{array}{ll}\text { モデルI } & \left(U_{I}=5\right) \\
\text { モデルII } & (\varepsilon=0.4)\end{array}$ & 4,384 & $\begin{array}{l}980 \\
853\end{array}$ & $\begin{array}{r}1,039(1.06) \\
890(1.04)\end{array}$ & $\begin{array}{r}1,134(1.16) \\
927(1.09)\end{array}$ \\
\hline
\end{tabular}

合，蓄熟系・配管系・熱㙨関などが二段に分割される ことになり，熱損失が相対的に增大するため，その 有効性は本解析結果よりむ更に低下する。従って，二 段構成の複合発電システムの導入は，システム構成が 複䧴になりコスト增を招くうえに，出力の向上む1割 以下と見込まれるので，積極的に導入する根拠伅えし いと考えられる。熱機関を更に三段，四段と結合させ るシステムも考えられるが，そのようなシステムの出 力堌大の上限活 $F$ モードで与えられ，9２7\%と算定 される。従って，熱機関を多尉洁合しても経済性向 上に対する寄与は小さいと結諭される。ただし，排熱 の有效利用という観点より熱機関の多段結合が必要な

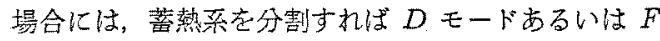
モードに近い值の出力の增大が期待し得るが，その割 合はあまり大きくないので蓄熱䒺，配管菜の設計には 十分唒慮することが必要である。

図 4(c)のシステムについては, 熱機関への入力が 不安定であるため, 熱傤関の性能が低下し $F$ モード の採用による 2 割程度の出力増大の可能性は相殺され てしまう可能性が強い。

図4(d)のシステムについては，非可逆性と熱容量 が図 4 (a)のシステム之同程度であるので， $F$ モード の有效性がそのまま当てはまると考元られる。このシ ステムはシステム構成が単純であるたる，コスト增を 招く要因が少ない，補助熱源を導入しているため出力 が安定化する，既設の火力発電設備住導入することが 可能であるなどの長所を有して凯り，有望なシステム 構成法であると考元られる。特に，図4(b)のシステ ムと比較した場合, 出力の向上之建設費の低下が可能 であり，経済性に優れたシステムであると結論され る。また，太晹エネルギーを中低温加熱に，化石然料 などの補助熱源を高温用の加熱に用いるととは，エネ ルギーの有効利用の面からも望ましいシステムであ る。

\section{4. まとめ}

太晹熱発電システムに扔ける集熱温度の最適設定法 に関してエクセルギーを基汇考察を行った。日本各地 の一年間の標準気象データを入力として，2種類の集 熱系のモデルを設定し，集熱温度の設定值が一段階の 場合, 二段階の場合㧍よび集熱温度に制限がない場合 について，集熱系加らの年間エクセルギー出力を求め た。

その結果, 日本各地の標準的気象条件の下では, 一 段階の集熱温度を設定した場合に比し，二段階の集效 温度を設定し, 日射入力に応じてエクセルボー出力の 高いほうの䈎熱温度を選択した場合には，年間エクセ ルギー出力の增大は 4〜 10\% 程度であることが判明し た。また，常にエクセルギー出力を最大とする集熱温 度で藮熱を行った場合には，年間エクセルギー出力は $9 \sim 27 \%$ 程度の增大が見込ま机るととが示された。と

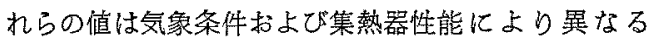
が，その傾向として熱損失係数の小さいほど，あるい は放射損失加相対的に顕著なほど有效性が低下するて とが判明した。

これらの結果より，二段階化禁熱温度を設定するた めに二段構成の複合発電システムを導入するととは， 出力の増大が 1 制以下と見積られ, システムの複維さ を勘案するとシステム㔍成上の有效性にそしいと結論 される。一方, 集熱フィールドでエクセルギ一効率孛 最大とする集熱温度で集熱在行い, 補助熱源で追加熟 を行った後，熱機関へ一定温度の熱を供給するシステ ムでは，2割程度の出力の増大が可能であるうえに， システム構成が単純である，出力が安定化するという 長所があり，有効性の高いシステム構成法であると結 諭される。ただし，本諭文でば複合発電の嶈入に伴う

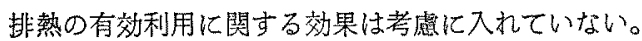
しかし，乙の観点上り複合発電を導入する場合にむ， 
後者のシステム構成を採用するほうが有效性は高くな る。

終わりに，本研究を進めるにあたりり終始有益な御助 言をいただいた本所エネルギー部太陽エネルギ一研究 室の方々に厚く感謝の意を表します。

(昭和 61 年 1 月 8 日受付, 同 61 年 7 月 3 日再受付)

\section{文献}

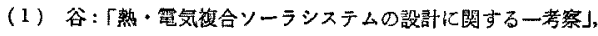
筺学馀 B 103,159 (昭 58-3)

（2）田中・沢田・建田・谷:「熱・䉓気衫合ソーラシステムの開

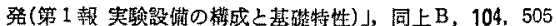
(昭 59-8)

（3）田中・津国・沢田・谷：「热・霞氮被合ソーラシステムの閶

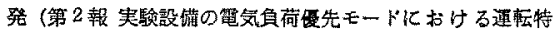
性) 週上B，104，513(昭 59-8)



z-

(5) A. Bejan, et al.: "Second Law Analysis and Synthesis of Solar Collector Systems", ASME Journal of Solar Energy Engineeing, 103, 23 (1981)

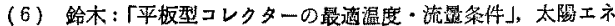
ルギー, 8, 5 (1982)

(7) M. Fuziwara: "Exergy Analysis for the Performance of Solar Collectors", ASME Journal of Solar Energy Engineering, 105, 163 (1983)

(8) J.A. Duffie \& W. A. Beckman: Solar Energy Thermal Processes, 146, 185 (1974) John Wiley and Sons

(9) V.E. Dudley \& R.M. Workhoven: "Performance Testing of the Hexcel Parabolic Trough Solar Collector", Sandia Laboratories, SAND 78-0381 (1978)

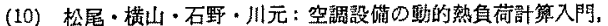
131 (昭 55) 日本建筑設诺士拹会

(11) R. Walraven: "Calculating the Position of the Sun", Sol. Energy, 20, 393 (1978)

(12) B.J. Wilkinson: "An improved FORTRAN program for the rapid calculation of the solar position", ibid., 27. 67 (1981) 